\title{
新型乾燥装置の乾燥性能について
}

\author{
清田正徳 ${ }^{1, \dagger}$, 福富純一郎 ${ }^{1}$, 西 健織 ${ }^{1}$, 寺島紀男 ${ }^{2}$ \\ 1 徳島大学大学院ソシオテクノサイエンス研究部, ${ }^{2}$ 株式会社マルミ
}

\section{Drying Performance of a New Type Drying Equipment}

\author{
Masanori KIYOTA ${ }^{1, \dagger}$, Junichiro FUKUTOMI ${ }^{1}$, Takeshi NISHI ${ }^{1}$, and Norio TERASHIMA ${ }^{2}$ \\ ${ }^{1}$ Institute of Technology and Science, Tokushima University, 2-1 Minami-jyosanjima, Tokushima 770-8506, Japan \\ ${ }^{2}$ Marumi Corporation, 230-1, Hanamen, Satoura, Naruto, Tokushima 772-0021, Japan
}

\begin{abstract}
By-product of tofu contains useful ingredients as well as water but it begins to smell quickly. Then it becomes industrial waste, but if it is dried, powders suitable for food material are obtained. A new type drying equipment is proposed for that purpose. It is composed of air heater, drying drum, classifying chamber and cyclone separator. Ceramic balls about $5 \mathrm{~mm}$ diameter are contained in the drying drum and move about at high speed entrained in the hot air. Wet materials are added to the drum by rotary feeder, dispersed by the action of balls and conveyed by the gas stream. At steady operating condition, fuel flow rate, air flow rate, temperature and humidity are measured. Drying is done mainly in the drum and partly in the classification chamber according to the obtained temperature drop. The measured humidity agrees well with the predicted value from the mass balance of steam. The energy used for evaporation of water in the material was about $80 \%$ of the provided energy. This dryer has the ability of drying wet materials in short time, continuously and efficiently without burning the material. But its drying capacity is relatively small and enlargement is necessary for industrial use.
\end{abstract}

Keywords: Wastes disposal, Dryer, Pneumatic conveyor, Dispersion, Ceramic ball

\section{1. 緒}

近年，環境問題がクローズアップされている状況下 において，企業の生産活動から排出される産業廃棄物, 生活污物などの処理が，ますます重要な問題となって いる，食品に関しては，産業廃棄物扱いとなる残飯や おから，焼酎かす，海産物などの廃棄物の処理に乾燥 器を利用しようとするニーズがあるとされている [1]. 一般に，被乾燥物により性質が異なるので，それぞれ に適した乾燥器を選ぶ必要がある [2-8]. 廃棄物の場合 も全く同様である。このうちおからの処理については, 単に焼却処分するのではなく，乾燥して乾燥粉末にし これを食材として再利用することが考えられている. おからは，含水率がとても高く，付着性が強いなどの 性質があるため，高温空気で乾燥しょうとすると，焦

(受付 2008 年 5 月 17 日，受理 2008 年 11 月 19 日

$1 \bar{T} 770-8506$ 徳島県徳島市南常三島町 2-1

2 ₹ 772-0021 徳島県鳴門市里浦町花面 230-1

† Fax: 088-656-9082, E-mail: kiyota@me.tokushima-u.ac.jp
げや変色が発生したり，さらには酸化，炭化まで生じ ることもある，焦げが発生すると，品質が低下して製 品を食材として使用できなくなる。そこで，セラミッ クボールを封入した乾燥ドラムと分級チャンバ，サイ クロン分離器よりなる新しい乾燥器を考案した. 簡単 な構造であり低コストでの製造が可能である。しかし ながら現状ではおからの処理量は比較的小さく, 産業 用に使用するためには大容量化が必要であり，そのた めには，性能を十分に把握しておく必要がある。そこ で本報告では，開発した乾燥器の性能を調べるために， 実験を行った。おからを投入して乾燥器を運転し，定 常になった状態でおからの供給速度，供給燃料流量， 空気流量, 温度分布, 湿度などのデータを得た。得ら れたデータを基に，装置全体のエネルギーバランスお よび水蒸気の質量バランスが成り立っているか調べる 事により，得られた性能值に矛盾がないか検討すると ともに，乾燥過程について考察した。 


\section{2. 実験装置および方法}

\section{1 新型乾燥装置と乾燥過程}

今回開発した乾燥装置の概形と寸法を Fig. 1 に示す. 本乾燥装置はホッパー部に付随する，被乾燥物を送り 込むロータリーフィーダを除いて回転・駆動部分がな くシンプルな構造になっている．本体の大きさは 3050 $\mathrm{mm} \times 2167 \mathrm{~mm} \times 1211 \mathrm{~mm}$ であり, サイクロン分離器の 上部に排気用の煙突がついている。乾燥機構を Fig. 2 に示す。被乾燥物であるおからはホッパーより投入し， ロータリーフィーダにより連続的に一定速度で下方の 乾燥ドラム内（直径 $400 \mathrm{~mm}$, 幅 $140 \mathrm{~mm}$ ）に送り込ま れる，乾燥に用いる熱風は熱風発生装置で発生してい る。ここでは燃料ガス（プロパン）をバーナで然やし て高温にしこれを用いて，下流部で流入する大量の空

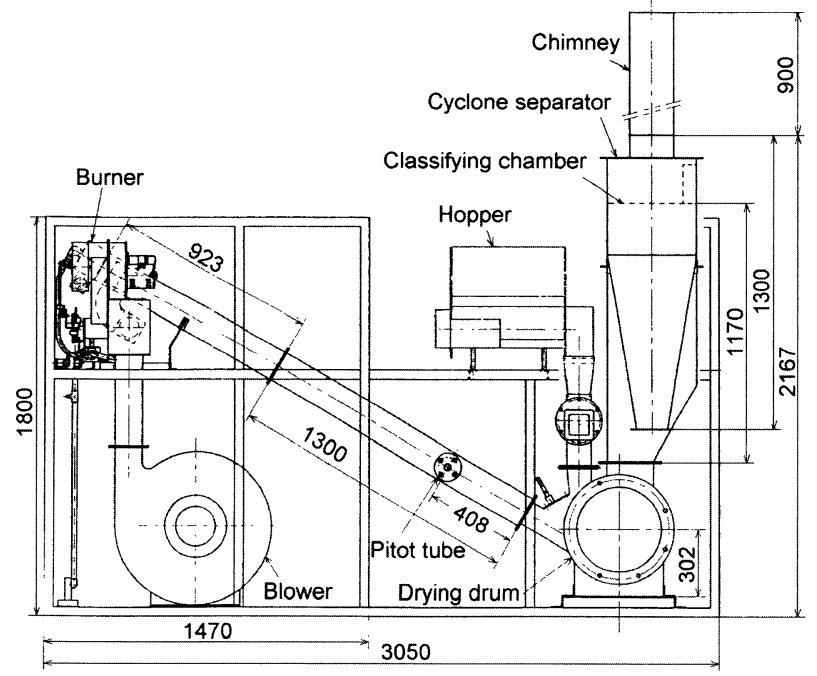

Fig. 1 Drying equipment.

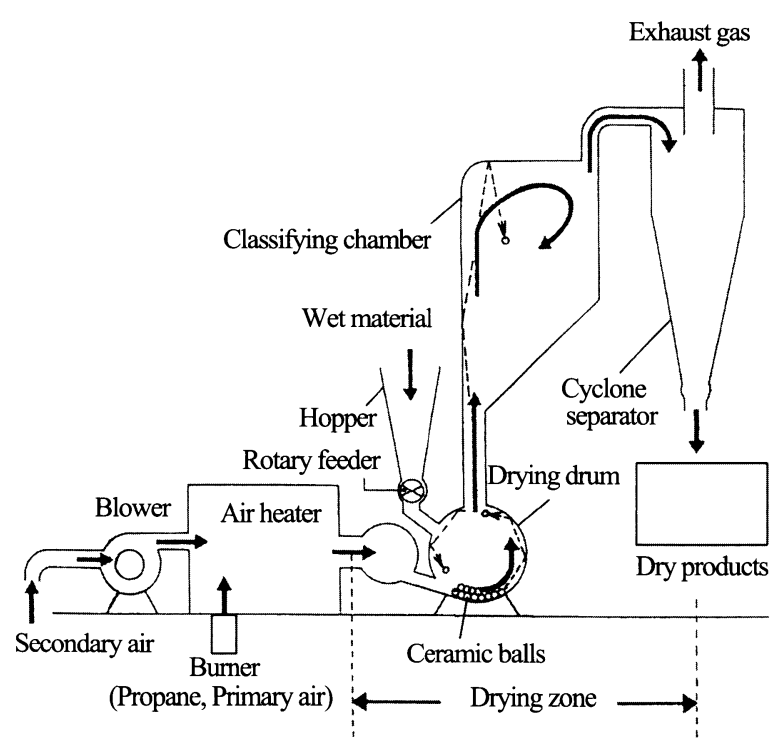

Fig. 2 Mechanism of drying.
気を加熱している. バーナ部で燃焼時に供給する空気 を 1 次空気，下流で供給する空気を 2 次空気とする. 乾燥室の入口温度が一定になるようにバーナを制御し ている。この熱風をノズルにより絞って高速流れとし て乾燥ドラムに接線方向に流入させている. ドラム内 には高速の旋回流が発生している。またドラム内には 直径が $5 \mathrm{~mm}$ のセラミックボールを入れてあり, 高速 の気流により旋回している. 被乾燥物はこの旋回流中 に投入されるので，ボールの衝撃により粉砕されて分 散し，気流により乾燥されながら運ばれる。おからは 壁にくつつきやすく焦げが発生しやすいが，ボールが 壁に当たる時にくっついたおからをかき落とす効果に よって焦げが発生せずに乾燥が行われる. ボールの封 入量は約 $2 \mathrm{~kg}$ である. 乾燥ドラムは上昇口によって分 級チャンバにつながっている。従って，おからは気流 にのって乾燥ドラムから上昇口を通過して，分級チャ ンバに送り込まれる.この行程で, 比較的大きな乾燥 物は内部まで乾燥されていないので，その自重で再び 落下して, 乾燥ドラム内に戻され, 再度粉砕と乾燥を 受けることになる。分級チャンバ内では熱風の上昇気 流で乾燥物を気流乾燥させているが速度が速くなりす ぎると被乾燥物が天井に付着したり，十分に乾燥され ていない被乾燥物がそのまま排出されたりする。これ を防ぐために，その断面を $400 \mathrm{~mm} \times 400 \mathrm{~mm}$ と広げて 流速を十分に減少させるとともに，高さを $1170 \mathrm{~mm}$ と して十分な体積を確保している. 分級チャンバでの気 流乾燥によって水分が蒸発し軽くなった固体粉末はサ イクロン分離器に流れてゆくが，十分に乾燥していな い重いものはチャンバ内を下降する．吹き上げてくる 熱風により再度気流乾燥され軽くなるとサイクロンに 流れてゆく，サイクロンとチャンバはFig. 1 で見ると チャンバ上部の点線の細長い矩形断面の通路でつな がっており，排出ガスはサイクロンに周方向に流入さ せている。サイクロンでは水蒸気を含んだ空気と乾燥 した粉末が分離される。サイクロン下部から製品が取 り出され，水蒸気を含んだ空気は上方の煙突から外部 に排出される.ところで, 本乾燥器は分類 $[2,3]$ としては, ドラム内でセラミックボールをべッド材とする流動層 におけるような乾燥をさせたあと，気流により乾燥お からは運ばれているので, 流動層乾燥器と気流乾燥器 の中間的な乾燥器といえる.

\section{2 測定装置および実験方法}

被乾燥物としておからを用い，おから乾燥時と非乾 燥時において以下の項目について測定した。これらの 值はデータロガーによりパソコンに取り込んで監視と 記録をした。

(1)ブロワ入口の空気流量……おから乾燥時に JIS 規格

[9]に定められた形状の入口ノズルで測定 
(2)プロパンガス流量……抢から乾燥時に熱風発生装置 入口に扔いてガス流量計で測定

(3) 乾燥ドラム入口の熱風量……ピトー管式流量計を用 いて測定 (Fig. 1 参照)

(4) 乾燥器内の温度……招から乾燥時に乾燥器内の各点 において乾燥器幅方向中央断面上でシース外径 $2.2 \mathrm{~mm}$ と $1 \mathrm{~mm}$ の $\mathrm{K}$ 型熱電対を用いて測定

(5) 乾燥器内の圧力……抢からを投入していない状態に おいて器内各部で直径 $1 \mathrm{~mm}$ の静压タップを用いて壁 面静圧の測定

(6) 乾燥器出口の湿度……扔から乾燥時に水蒸気を含ん だ排気流の相対湿度をサイクロン分離器上部の煙突内 で測定

(7) 乾燥前と乾燥後のおからの水分含有量……八ロゲン 水分計により測定. 試料約 $20 \mathrm{~g}$ をハロゲンランプによ り加熱して完全に乾燥させ, その質量変化から求めて いる。值は湿量基準である。

\section{3. 実験結果}

\section{1 本乾燥装置の基本性能}

Fig. 1 に示した本乾燥装置を用いておからの乾燥実験 を行った。乾燥器に供給するおからは水分含有率（湿 量基準）が 78〜 80\%であるが，これが乾燥装置を出る と 6 〜 $10 \%$ になっている。扔からの乾燥器への供給速度 は $50 \mathrm{~kg} / \mathrm{h}$ である。抢からの乾燥時間（被乾燥物の滞 留時間）は被乾燥物投入から目視による計測で約 5 秒 である。問題となる焦げも発生することなく連続運転 することが可能であった，得られた乾燥おからは $1 \mathrm{~mm}$ に満たない微細な粉末状態で食材として利用可能な状 態である. Table 1 に主な測定結果をまとめてある.

\section{2 乾燥装置内部の温度分布}

乾燥器内の温度測定のために, Fig. 3(a) に示す 22 力 所に熱電対を取り付けた。これらの測定值から描画ソ フトにより等温線を求めた。サンプル点から任意の点 の值を相関法 [11] により求めて等高線を得ている。 そ の温度分布が Fig. 4 である. 座標軸は寸法を mm で表す. この図の左上部にサイクロンへ至る通路がある。被乾

Table 1 Obtained results.

\begin{tabular}{ll}
\hline Feed rate & $50 \mathrm{~kg} / \mathrm{h}$ \\
Fuel flow rate & $1.176 \mathrm{~m}_{\mathrm{N}}^{3} / \mathrm{h}$ \\
Secondary air & $260 \mathrm{~m}_{\mathrm{N}}^{3} / \mathrm{h}$ \\
Water content & Before drying $78 \sim 80 \%$ \\
Water content & After drying $6 \sim 10 \%$ \\
Air & $100 \mathrm{kPa}, 30^{\circ} \mathrm{C}$, humidity $60 \%$ \\
Exhaust gas & $100 \mathrm{kPa}, 79^{\circ} \mathrm{C}$, humidity $35 \%$ \\
\hline
\end{tabular}

燥物であるおからを投入して運転している状態で, 乾 燥器入口の温度は $350^{\circ} \mathrm{C}$ であるが, 乾燥ドラム出口では 106 $130^{\circ} \mathrm{C}$ 程度となる。 また上昇通路出口で 93〜 $112^{\circ} \mathrm{C}$ となり，分級チャンバ出口では約 $88^{\circ} \mathrm{C}$ とっている. これらの高温部をたどって被乾燥物は運ばれると考え ると，ドラム内での温度低下は $220^{\circ} \mathrm{C}$ となる。た，上 昇通路部で約 $18^{\circ} \mathrm{C}$ の低下をし, 残り $24^{\circ} \mathrm{C}$ の温度降下は チャンバ内で生じている. ガス温度の温度降下の際に ガスが放出した熱は全ておからの水分の蒸発に使われ ているとす机ば，全体の $84 \%$ は乾燥ドラム内で生じて いる事になる。また通路部で $7 \%$, チャンバ内で $9 \%$ が (a) Temperature

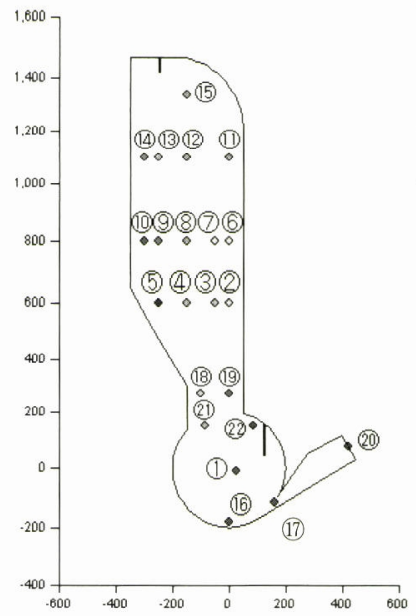

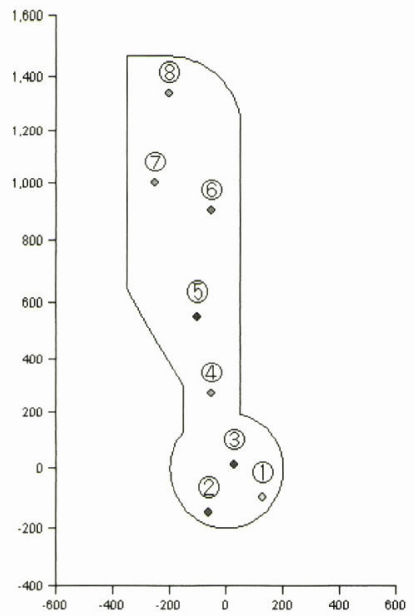

(b) Pressure
Fig. 3 Measurement positions.

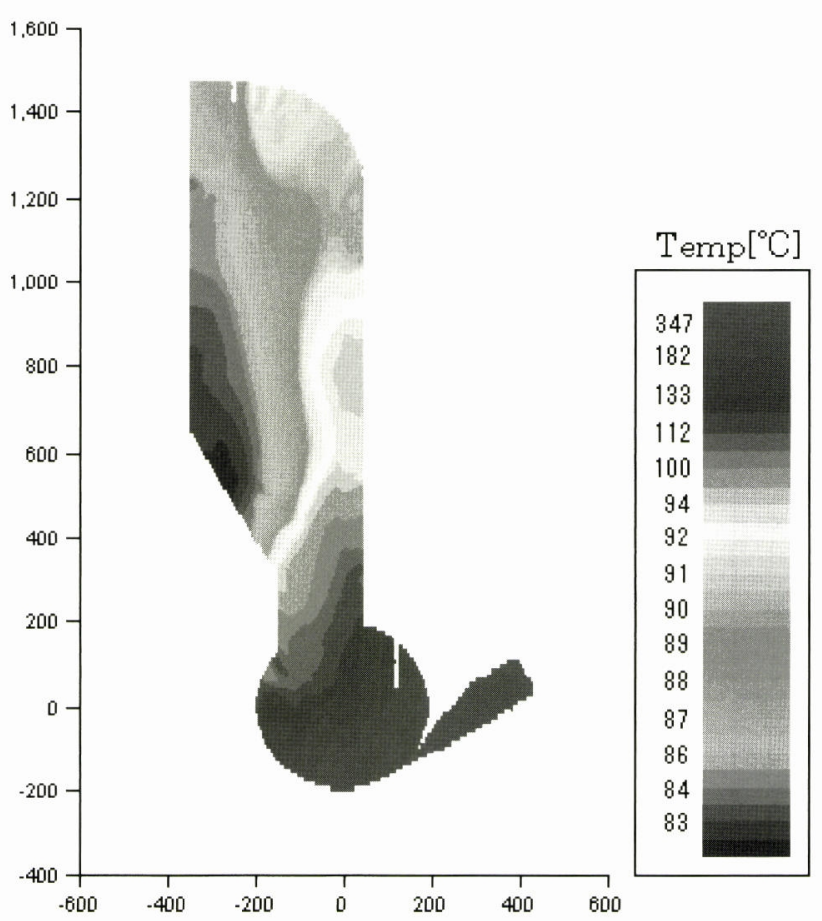

Fig. 4 Temperature distribution. 
蒸発している事になる。ドラム内では扔からを高速の 気流とボールの力で吹き飛ばしているのであるが，己 れがうまくいけば扔からは分散され表面積が広くなる のでただちに乾燥されると考えられる。チャンバ内で は流れに沿っておからが運ばれるため，チャンバ右側 壁 $(x=50)$ に沿って上昇するとともに温度が降下し， 大半のガスは排気口から流出する。チャンバ左側壁下 部 $(x=-350)$ において $82^{\circ} \mathrm{C}$ となり温度が最も低くなっ ている。これは水分が多く重いおからが左側壁に沿っ て下降し集まってくるためであると思われる。またド ラムに続く上昇通路部で水平方向に温度が一様でなく, 右側壁 $(x=50)$ に近づくほど温度が高くなっている. ドラム内の高温気流の周方向速度成分が大きく，その 影響で右側壁では温度は高くなるが，左側壁 $(x=-$ 150）はその影響が少なくチャンバから戻ってくる湿っ たおからの影響を受けて温度が低くなる.

\section{3 乾燥装置内部の圧力分布}

圧力を Fig. 3(b) に示す 8 カ所で測定した。サンプル 点は少ないがこれを基に等高線を求めて得た圧力分布 を Fig. 5 に示す。ドラム内に拈いてはノズル出口付近 は200 Pa で最も低く，ドラム周辺部はこれに沿って流 れる際に遠心力を受けるため圧力が高くなり，最大で $230 \mathrm{~Pa}$ となっている。ドラム出口からチャンバの右側 壁に沿ってほぼ一様に压力が減少した後，天井部へか けて圧力が回復している。チャンバ内では流れは右側 壁では直線的に上昇するのに対して左側では循環流に

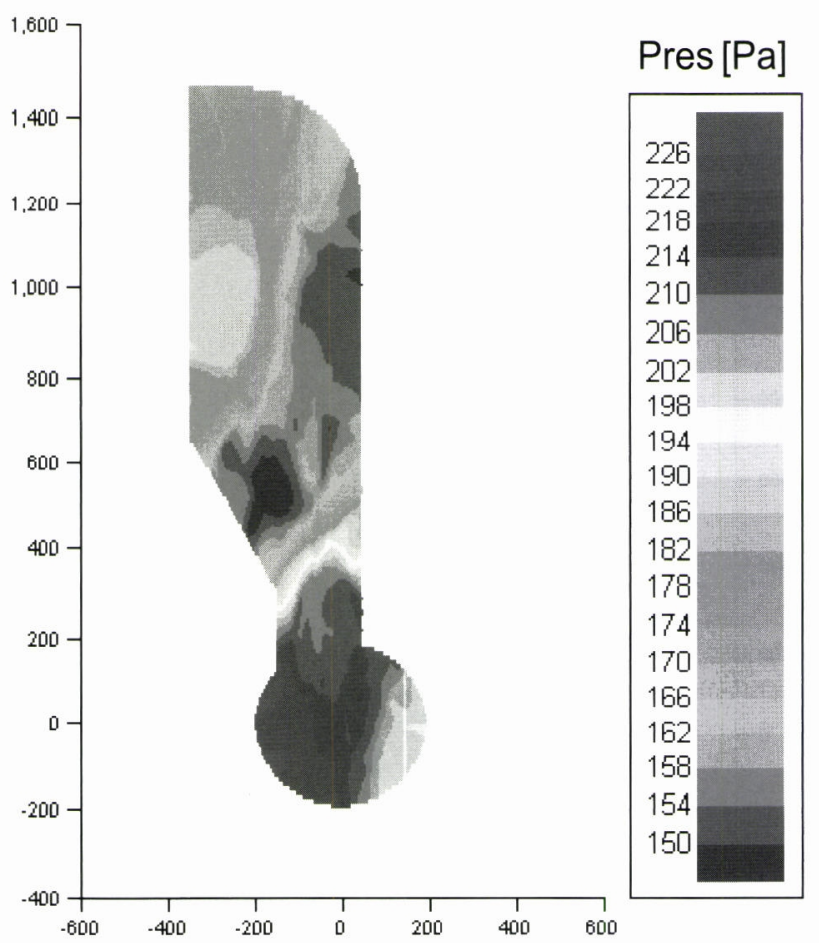

Fig. 5 Pressure distribution.
より流れが曲げられるために左側で高めの值を示して いる．チャンバ入口部では上昇流と下降流の混合が起 きるため圧力損失が生じ大きな圧力降下が生じている と考えられる。また乾燥ドラム出口の速度を, 空運転 に扔いて熱線風速計により測定した。ドラム出口上昇 口の中央の断面上に 6 点設置したが，平均速度はおよ そ $7 \mathrm{~m} / \mathrm{s}$ であった。次節で述べる高温ガスのガス量か ら同位置での風速を求めてみると $6.8 \mathrm{~m} / \mathrm{s}$ となり, よく 一致していることがわかる。この気流により被乾燥物 は分級チャンバに運び込ま机る。おからを投入してい る状態ではおからの粉末の軌跡から流れの様子が観察 できる。乾燥ドラム内では Fig. 4 において, 入口ノズ ルから高速気流がドラムの周に沿って吹き込んでいる ので，これにひきずられてドラム内に右回りの旋回流 ができている。上部のチャンバ内では，右側壁に沿っ て上昇する流れと左側壁に沿って下降する流れがあり, これによって左回りの旋回流ができている。乾燥ドラ ム内のボールは高速気流にのって高速で移動し, 大半 はドラム内で旋回するが，一部は上部のチャンバに達 するものもある.

\section{4. 乾燥装置の熱的評価}

乾燥器の運転時の状態が合理的であるかを調べるた めに，水蒸気の質量バランスとエネルギーバランスに ついて検討する.

\section{1 乾燥器内の水蒸気の質量バランス}

水蒸気には，空気中に含ま机ている水蒸気，燃料中 の水素が燃えて発生する水蒸気，おからに含まれてい る水分が蒸発して発生する水蒸気の 3 つが考えられる. 供給空気はバーナ部で燃焼に利用する一次空気と下流 で供給する大量の二次空気がある。一次空気の空気過 剩率は 1.3 である。二次空気量は取り入れ口を計測ノズ ルとして測定してある。乾燥器の運転時の状態は Table 1 によりわかる. 怙からの供給量 $50 \mathrm{~kg} / \mathrm{h}$ とおからの含 水率の值より, 固形分と水分の流量が求まる。また燃 料のプロパンガスの供給量は $1.176 \mathrm{~m}_{\mathrm{N}}^{3} / \mathrm{h}$, 燃焼用一次 空気拉よび後流部で加えた二次空気量の測定值はそれ ぞれ $37.35 \mathrm{~m}_{\mathrm{N}}^{3} / \mathrm{h}, 260 \mathrm{~m}_{\mathrm{N}}^{3} / \mathrm{h}$ であった. $\mathrm{m}_{\mathrm{N}}^{3}$ は標準状 態における体積である。また燃焼に関する計算を容易 にするために, 燃料ガス $1 \mathrm{~m}_{\mathrm{N}}^{3} / \mathrm{h}$ あたりについての計 算を行うことにする。空気の入口状態は $100 \mathrm{kPa}$, $30^{\circ} \mathrm{C}$, 相対湿度 $60 \%$ なので入口空気の絶対モル湿度 $x$ は 0.0260 である。燃料ガスは $\mathrm{C}_{3} \mathrm{H}_{8}$ として燃焼ガス量, 発生水蒸気量を求めた。燃焼は

$$
\mathrm{C}_{3} \mathrm{H}_{8}+5 \mathrm{O}_{2} \rightarrow 3 \mathrm{CO}_{2}+4 \mathrm{H}_{2} \mathrm{O}
$$

と表せるのでプロパン $1 \mathrm{~m}_{\mathrm{N}}^{3}$ の燃焼の際, $5 \mathrm{~m}_{\mathrm{N}}^{3}$ の酸素 
を消費し $7 \mathrm{~m}_{\mathrm{N}}^{3}$ の燃焼ガスを発生する. 空気で燃やす 場合に発生するガス量 $v_{1} \mathrm{~m}_{\mathrm{N}}{ }^{3}$ は次式で表せる [10].

$$
\begin{gathered}
L_{0}=5 / 0.21 \\
v_{1}=\{(1+x) \mu-0.21\} L_{0}+7
\end{gathered}
$$

ここで $L_{0} \mathrm{~m}_{\mathrm{N}}{ }^{3}$ は理論空気量 (乾き空気量)， $\mu$ は空気過 利率, $x$ は空気の絶対モル湿度である. 燃焼ガス $v_{1} \mathrm{~m}_{\mathrm{N}}{ }^{3}$ 中の水蒸気量 $v_{1 \mathrm{H}_{2} \mathrm{O}} \mathrm{m}_{\mathrm{N}}{ }^{3}$ は空気中の水蒸気と燃焼により 発生する $4 \mathrm{~m}_{\mathrm{N}}^{3}$ を加えたものなので,

$$
v_{1 \mathrm{H}_{2} \mathrm{O}}=x \mu L_{0}+4
$$

となる。また燃焼ガス中の，乾きガス量は

$$
v_{\mathrm{dry}}=v_{1}-v_{1 \mathrm{H}_{2} \mathrm{O}}
$$

である. Table 2 はおからの供給速度, 燃料流量, 空気 流量をまとめたものであるが，右の欄に燃料 $1 \mathrm{~m}_{\mathrm{N}}{ }^{3} / \mathrm{h}$ に対応する值を示してある. Table 2 において全空気は 一次空気と二次空気を合わせたもので，全乾き空気と 理論空気の比 $\mu$ を求めると 10.35 となる. また燃焼ガス 中の乾きガス量 $v_{\mathrm{dry}}$ は乾燥器出口でも同じ量で, 水蒸 気量は, 乾燥室内で発生する水蒸気の分だけ増加して 乾燥器を出てゆく.

運転状態での水蒸気の質量バランスを $\mathrm{m}_{\mathrm{N}}^{3}$ で考える. おからの供給速度を $M_{1} \mathrm{~kg} / \mathrm{h}$, 乾燥おからの回収速度 を $M_{2} \mathrm{~kg} / \mathrm{h}$, 燃料流量を $F \mathrm{~m}_{\mathrm{N}}^{3} / \mathrm{h}$, 出口ガスの絶対モ ル湿度を $x_{2}$ とすると質量バランスの式は以下のように なる。

$$
F v_{1 \mathrm{H}_{2} \mathrm{O}}+\left(M_{1}-M_{2}\right) \times \frac{22.4}{18}=F v_{\text {dry }} x_{2}
$$

左辺は, 燃焼ガス中の水蒸気とおからから発生する水 蒸気である。これらが煙道から排出されるので, 右辺 の出口ガス中に含まれる水蒸気と等しくなるはずであ

\begin{tabular}{|c|c|c|c|c|}
\hline \multirow{2}{*}{ Wet material } & \multicolumn{2}{|c|}{$50 \mathrm{~kg} / \mathrm{h}$} & \multicolumn{2}{|c|}{$42.52 \mathrm{~kg} / \mathrm{h}$} \\
\hline & solid & water & solid & water \\
\hline inlet & 11 & 39 & 9.354 & 33.166 \\
\hline outlet & 11 & 0.96 & 9.354 & 0.816 \\
\hline Fuel & \multicolumn{2}{|c|}{$1.176 \mathrm{~m}_{\mathrm{N}}^{3} / \mathrm{h}$} & \multicolumn{2}{|c|}{$1 \mathrm{~m}_{\mathrm{N}}^{3} / \mathrm{h}$} \\
\hline Air & $\begin{array}{c}\text { wet } \\
\mathrm{m}_{\mathrm{N}}^{3} / \mathrm{h}\end{array}$ & $\underset{\mathrm{m}_{\mathrm{N}}^{3} / \mathrm{h}}{\mathrm{dry}}$ & $\begin{array}{c}\text { wet } \\
\mathrm{m}_{\mathrm{N}}^{3} / \mathrm{h}\end{array}$ & $\begin{array}{c}\mathrm{dry} \\
\mathrm{m}_{\mathrm{N}}^{3} / \mathrm{h}\end{array}$ \\
\hline Theory & & 28.00 & & 23.81 \\
\hline primary & 37.35 & 36.40 & 31.76 & 30.95 \\
\hline secondary & 260.0 & 253.4 & 221.1 & 215.5 \\
\hline total & 297.3 & 289.8 & 252.8 & 246.4 \\
\hline
\end{tabular}
る. 入口空気, 乾燥ドラム入口, 乾燥器出口における 全ガス量, 乾きガス量, 水蒸気量の值を Table 3 にまと

\begin{tabular}{|c|c|c|c|c|c|c|}
\hline $\begin{array}{l}\text { Feed } \\
\text { rate }\end{array}$ & \multicolumn{3}{|c|}{$50 \mathrm{~kg} / \mathrm{h}$} & \multicolumn{3}{|c|}{$42.52 \mathrm{~kg} / \mathrm{h}$} \\
\hline Fuel & \multicolumn{3}{|c|}{$1.176 \mathrm{~m}_{\mathrm{N}}^{3} / \mathrm{h}$} & \multicolumn{3}{|c|}{$1 \mathrm{~m}_{\mathrm{N}}^{3} / \mathrm{h}$} \\
\hline Gas & $\begin{array}{c}\text { wet } \\
\mathrm{m}_{\mathrm{N}}^{3} / \mathrm{h}\end{array}$ & $\begin{array}{c}\text { dry } \\
\mathrm{m}_{\mathrm{N}}^{3} / \mathrm{h}\end{array}$ & $\begin{array}{c}\text { water } \\
\text { vapor } \\
\mathrm{m}_{\mathrm{N}}^{3} / \mathrm{h}\end{array}$ & $\begin{array}{c}\text { wet } \\
\mathrm{m}_{\mathrm{N}}^{3} / \mathrm{h}\end{array}$ & $\underset{\mathrm{m}_{\mathrm{N}}^{3} / \mathrm{h}}{\mathrm{dry}}$ & $\begin{array}{l}\text { water } \\
\text { vapor } \\
\mathrm{m}_{\mathrm{N}}{ }^{3} / \mathrm{h}\end{array}$ \\
\hline air & 297.3 & 289.8 & 7.535 & 252.8 & 246.4 & 6.41 \\
\hline inlet & 299.7 & 287.5 & 12.24 & 254.8 & 244.4 & 10.41 \\
\hline exit & 347.0 & 287.5 & 59.58 & 295.1 & 244.4 & 50.67 \\
\hline
\end{tabular}
めてある. 燃料流量 $F$ を $1 \mathrm{~m}_{\mathrm{N}}^{3} / \mathrm{h}$ とした場合の值も併

Table 2 Flow rates of wet material and air.
Table 3 Gas flow rates.

記してある。おからは $78 \%$ の水分割合から $8 \%$ の水分割 合に減少するのでこれに伴って燃料 $1 \mathrm{~m}_{\mathrm{N}}^{3} / \mathrm{h}$ について $32.35 \mathrm{~kg} / \mathrm{h}$ の水分が蒸発する. 体積で $40.26 \mathrm{~m}_{\mathrm{N}}^{3} / \mathrm{h}$ で ある。これを合わせたものが出口ガスとなる。また， 式 (6) より, 乾燥器出口の絶対モル湿度 $x$ は 0.208 と求 まる. 出口状態は実測の結果 $79^{\circ} \mathrm{C}, 100 \mathrm{kPa}$ であった のでこれらより出口相対湿度は $37.8 \%$ と求まる. 出口 における相対湿度の実測值は $32 \sim 34 \%$ である。一方湿 度計の精度は表示值 $\pm 2.1 \%$ 湿度であり校正の不確かさ が $1.0 \%$ 湿度あるとされており，全体で $\pm 3.1 \%$ の湿度 の測定誤差が見込まれる．従っておおよそ誤差の範囲 で一致しており，水蒸気の流れについては無理がなく 説明できると考えて良い.

\section{2 乾燥器内のエネルギーバランス}

運転状態におけるエネルギーバランスについて検討 する，入口空気温度を基準温度とすると，エネルギー バランスは以下のようになる。

$$
\begin{aligned}
F q_{\mathrm{f}}+W= & F v_{\mathrm{dry}} c\left(t_{2}-t_{\mathrm{air}}\right)+F v_{1 \mathrm{H}_{2} \mathrm{O}} c_{\mathrm{w}}\left(t_{2}-t_{\mathrm{air}}\right) \\
& +\left(M_{1}-M_{2}\right) h_{\mathrm{v}}+M_{2} c_{\mathrm{s}}\left(t_{2}-t_{\text {air }}\right)+Q
\end{aligned}
$$

入口空気温度を $t_{\mathrm{air}}$ 出口ガス温度を $\mathrm{t}_{2}$ とする. $q_{\mathrm{f}} \mathrm{kJ} /$ $\mathrm{m}_{\mathrm{N}}^{3}$ は燃料の低位発熱量, $W \mathrm{~kJ} / \mathrm{h}$ は送風機動力, $c \mathrm{~kJ} /$ $\mathrm{m}_{\mathrm{N}}^{3} \mathrm{~K}$ は乾きガスの比熱, $c_{\mathrm{w}} \mathrm{kJ} / \mathrm{m}_{\mathrm{N}}{ }^{3} \mathrm{~K}$ は水蒸気比熱, $h_{\mathrm{v}}$ $\mathrm{kJ} / \mathrm{kg}$ は水蒸気のエンタルピ, $c_{\mathrm{s}} \mathrm{kJ} / \mathrm{kgK}$ は乾燥後のお からの比熱, $Q \mathrm{~kJ} / \mathrm{h}$ は放熱量である. 左辺は燃料の発 熱量と送風機動力である. 右辺は乾き燃焼ガスのエン タルピ，燃焼ガス中のおからからの発生分は除いた水 蒸気のエンタルピ, おからより発生した水蒸気のエン タルピ, 出口のおからのエンタルピ, 乾燥器からの放 熱量の和である. 熱風の乾きガスのエンタルピを求め るためにはその比熱の值が必要である．熱風の乾きガ スのモル分率と比熱および水蒸気の比熱を Table 4 に示 す.プロパンの低位発熱量は $2044 \mathrm{MJ} / \mathrm{kmol}$ なのでバー ナ部での供給熱量は $107 \mathrm{MJ} / \mathrm{h}$ である。また送風機での 供給エネルギーは $5 \mathrm{~kW}(18 \mathrm{MJ} / \mathrm{h})$ である。これらが すべて供給空気の加熱に使われるとすれば合計 125 $\mathrm{MJ} / \mathrm{h}$ のエネルギーが加えられることになる。一方，乾 燥室入口温度は $350^{\circ} \mathrm{C}$ に制御されている。 ガスのもつ熱 
Table 4 Gas composition and specific heat.

\begin{tabular}{cc}
\hline Gas & $\begin{array}{c}\text { Specific heat } \\
\mathrm{kJ} / \mathrm{m}_{\mathrm{N}}{ }^{3} \mathrm{~K}\end{array}$ \\
\hline $\begin{array}{c}\text { dry gas } \\
\left(\mathrm{N}_{2}: \mathrm{O}_{2}: \mathrm{CO}_{2}=0.7957: 0.1933: 0.0109\right) \\
\text { water vapor }\end{array}$ & $c=1.304$ \\
\hline
\end{tabular}

量は $125.5 \mathrm{MJ} / \mathrm{h}$ となり加熱量とほぼ一致している. 乾 燥室でおからは含まれている水分が $38.04 \mathrm{~kg} / \mathrm{h}$ だけ蒸 発する. おから中の水分が, 乾燥器を出るときにもっ ているエネルギーは乾燥前の湿ったおからの $30^{\circ} \mathrm{C}$ を基 準として，水 $1 \mathrm{~kg}$ あたりに

$$
h_{\mathrm{v}}=1.86 \times(79-30)+2500=2591 \mathrm{~kJ} / \mathrm{kg}
$$

なので，全体では $98.6 \mathrm{MJ} / \mathrm{h}$ となる. 乾燥後のおから の保有エネルギーはその比熱を $2 \mathrm{~kJ} / \mathrm{kgK}$ として 1.08 $\mathrm{MJ} / \mathrm{h}$ である．燃焼ガスに由来する残りのガスがもつ熱 は $19.4 \mathrm{MJ} / \mathrm{h}$ である. 乾燥ドラムでは入口温度は $350^{\circ} \mathrm{C}$ であり，ここで熱風がもっていた熱から，上で求めた 出口で持つ熱を差し引くと $6 \mathrm{MJ} / \mathrm{h}$ が周囲に放熱されて いることになる. エネルギーの流れを Fig. 6 にまとめ て示す.

エネルギーの流れは以上のようになっていると考え られる. 燃料ガスの発生熱と送風機の消費動力の合計 に対するおからの乾燥に使われた熱量の割合を効率と すれば効率は $79.7 \%$ となっている.この值は一般的な 乾燥装置の值に比べて高い值を示している.

以上のように水蒸気のバランスから見ても，エネル ギーのバランスから見ても矛盾がなく，実験結果は妥 当な值が得られていると考えられる.

\section{5. 結言}

提案した新型乾燥器を用いておからの乾燥実験を行 い, 乾燥器内の熱流動について検討した結果, 以下の ことが明らかとなった。
(1)本乾燥器では乾燥ドラム内でセラミックボールと高 速の気流によって被乾燥物を粉砕, 分散して, 被乾燥 物を焦がすことなく連続的に乾燥できている.

(2)ドラム内とチャンバ内には，それぞれ互いに逆向き の旋回流が生じており, 被乾燥物は気流に沿ってなめ らかに運ばれている。

(3)乾燥のほとんどはドラム内で行われており, チャン バに入った被乾燥物のうち, 水分が多くて重い被乾燥 物はドラムに戻り，水分を含むが比較的軽いものは流 れに沿ってチャンバ内に運ばれ気流乾燥を受けている.

(4) 乾燥器内の水蒸気の質量バランスから求められる出 口の湿度は, 実験結果の出口湿度と一致しており, 乾 燥装置内での水蒸気発生のメカニズムが確認できた。

(5) 乾燥器内の熱量バランスから乾燥における熱効率は $80 \%$ 程度となることが確認できた.

(6) 今回開発した乾燥器は比較的小容量であり産業用に 使用するためには大容量化が必要で，そのためにはド ラムおよびチャンバ内の流れについてさらに詳しく検 討することが必要である.

\section{Nomenclature}

c : heat capacity of dry combustion gas, $\mathrm{kJ} / \mathrm{m}_{\mathrm{N}}{ }^{3} \mathrm{~K}$

$c_{\mathrm{w}}$ : heat capacity of water vapor, $\mathrm{kJ} / \mathrm{m}_{\mathrm{N}}{ }^{3} \mathrm{~K}$

$c_{\mathrm{s}}$ : heat capacity of dried product, $\mathrm{kJ} / \mathrm{m}_{\mathrm{N}}{ }^{3} \mathrm{~K}$

$F \quad$ : flow rate of fuel gas, $\mathrm{m}_{\mathrm{N}}^{3} / \mathrm{h}$

$h_{\mathrm{v}} \quad$ : enthalpy of water vapor, $\mathrm{kJ} / \mathrm{kg}$

$L_{0}$ : volume of theoretical air for $1 \mathrm{~m}_{\mathrm{N}}^{3}$ fuel gas, $\mathrm{m}_{\mathrm{N}}{ }^{3}$

$M$ : feed rate of wet material, $\mathrm{kg} / \mathrm{h}$

$q_{\mathrm{f}} \quad$ : lower heating value of fuel, $\mathrm{kJ} / \mathrm{m}_{\mathrm{N}}{ }^{3}$

$Q \quad:$ heat loss, $\mathrm{kJ} / \mathrm{h}$

$t \quad$ : temperature, ${ }^{\circ} \mathrm{C}$

$v$ : combustion gas volume for $1 \mathrm{~m}_{\mathrm{N}}^{3}$ fuel gas, $\mathrm{m}_{\mathrm{N}}{ }^{3}$

$v_{\text {dry }}$ : dry combustion gas volume for $1 \mathrm{~m}_{\mathrm{N}}^{3}$ fuel gas, $\mathrm{m}_{\mathrm{N}}^{3}$

$v_{\mathrm{H}_{2} \mathrm{O}}$ : water vapor volume in combustion gas for $1 \mathrm{~m}_{\mathrm{N}}^{3}$

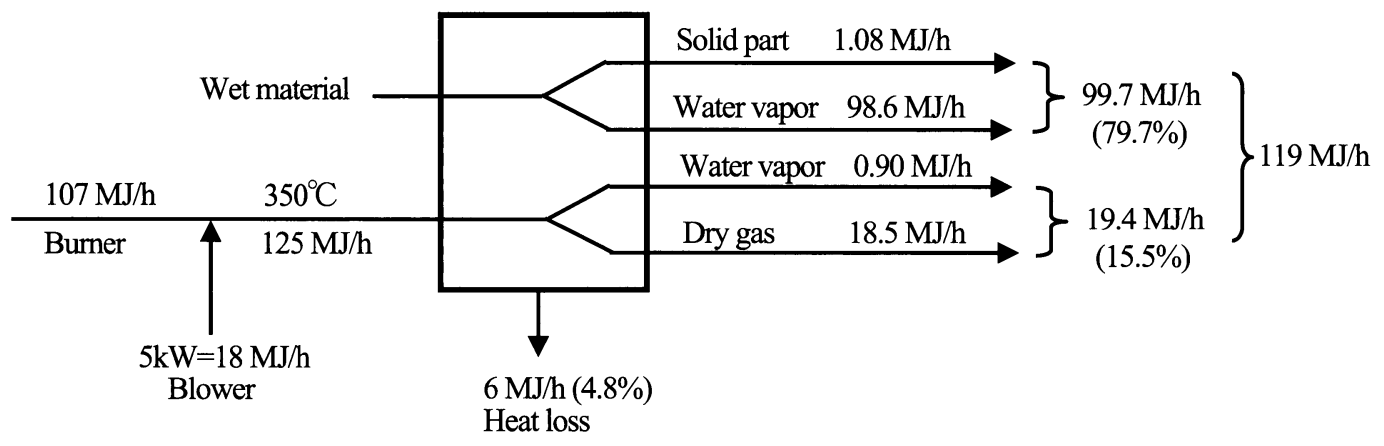

Fig. 6 Energy flow in the dryer. 
fuel gas, $\mathrm{m}_{\mathrm{N}}^{3}$

$W$ : power input to the blower, $\mathrm{kJ} / \mathrm{h}$

$x$ : absolute molar humidity of air, -

$\mu$ : excessive air ratio, -

\section{Subscript}

air : surrounding air

1 : at inlet of the drying drum

2 : at exit of the dryer

\section{引用 文 献}

[1] Trend of development of drying equipments -Special report on new technologies of food drying (in Japanese), Shokuhin to Kaihatsu, 37(12), 14-17 (2002).

[2] A. Kubota; "Drying equipments, 2nd edition (Kansou Souchi)", The Energy Conservation Center, Tokyo, Japan, 2004.

[3] R. Kirie; "Drying, 4th edition (Kansou)", Kagaku Kogyo Sya, Tokyo, Japan, 2002.

[4] Introduction of heating and drying equipments developed by several makers-Special report on heating and drying technologies of food (in Japanese), Japan Food Science, 42(3), 38-42 (2003).

[5] H. Takashima; Drying equipments for adhesive materials using swirling air flow(in Japanese), Kagaku Souchi, 45(9), 55-60 (2003).

[6] T. Ishihara, M. Yokosuka, T. Arai, New concept dryer with preforming process (in Japanese), Kagaku Souchi, 43(6), 122-126 (2001).
[7] K. Wakiya, Drying equipments (in Japanese), Kagaku Souchi, 40(4), 91-94, (1998).

[8] K. Tabata, Liquefied materials dryer with preforming and fluidization (in Japanese), Powder Science and Engineering, 36(2), 43-50 (2004).

[9] "JIS8330, Testing methods for turbo fans (Sofuki Shikenho)", Japanese Standards Association, Tokyo, Japan, p.8, 1962.

[10] M. Numano, T. Nakajima, N. Kamo, "Steam engineering (in Japanese)”, Asakura Syoten, Tokyo, Japan, p.42, 1987.

[11] J. C. Davis; "Statistics and data analysis in geology", John Wiley \& Sons, p.383, 1986.

要 旨

豆腐の製造過程で発生するおからは産業廃棄物扱い となり，その処理法の1つとして乾燥して再利用しよ うという考えがある。そこで，乾燥ドラムと分級チャ ンバ, サイクロン分離器よりなる新しい乾燥器を考案 した. ドラムには直径 $5 \mathrm{~mm}$ のセラミックボールが入 れてあり，おからはこれにより粉砕され熱風により流 動化している。扔からを投入した運転状態で供給然料 流量, 空気流量, 温度分布, 湿度などの測定を行った. ガスの温度降下から乾燥の大半はドラム内で行われて いる. 乾燥器内の水蒸気の質量バランスから求められ る装置出口の湿度は, 測定した出口湿度と良く一致し ており，運転状態が合理的である事を示している。 ま た乾燥器内の熱量バランスから乾燥装置の熱効率は $80 \%$ 程度となる。今回開発した装置により焦げを発生 することなく連続的に効率よく乾燥できる事がわかっ たが, 比較的小容量なので大容量化する必要がある. 